\title{
CULTURAL IDENTITY IN BELOVED
}

Ayşegül ELÇi ${ }^{1}$

Geliş: 30.10 .2020 / Kabul: 24.03.2021

DOI: 10.29029/busbed.816663

\section{Abstract}

This study aims to analyse the novel Beloved by Toni Morrison in terms of cultural identity through post-colonial perspective. In Beloved which deals with slavery in America in nineteenth century, by portraying a true history of a Black slave mother, Morrison reflects the voice of voiceless, sufferers, and others who are shut from any contentment in life. She represents bluntly the unpleasant experiences of constructing identity in the shadow of racism. The novel illustrates the hardships and pressure grieved by the slaves of a farm called Sweet Home in the period of the Civil War focusing on the misery of Sethe's poor, depressed family. In this study, the factors affecting African American identity and the process of constructing the cultural identity of African Americans are discussed through viewing the period's deep-seated developments.

Keywords: Beloved, Slavery, African Americans, Blacks, Cultural Identity, and Hybridity.

\section{SEVILEN ADLI ESERDE KÜLTÜREL KIMLIKK}

\section{$\ddot{O} z$}

Bu çalışma, Toni Morrison'un Sevilen adlı romanını kültürel kimlik bağlamında, post-coloniyel bir bakış açısıyla, ele almayı hedeflemektedir. Morrison, on dokuzuncu yüzyıldaki köleliği ele alan Sevilen adlı eserde, siyahî anne bir kölenin gerçek hayat hikâyesini işleyerek, sömürülenlerin, ezilenlerin ve çaresizlerin sessiz çı̆̆lıklarını yansıtmaktadır. Irkçılığın gölgesinde, yeni bir kimlik oluşturmanın zorluklarını aktarmaktadır. Roman, Amerika'nın iç savaş yıllarında (1861-1865) Tatlı Ev çiftliğindeki Sethe adındaki siyahî kölenin ve ailesinin acılarını, ıstıraplarını ve yaşantılarındaki zorlukları ele almaktadır. Bu çalışmada, Amerikalı

\footnotetext{
${ }^{1}$ Doktora Öğrencisi, İstanbul Aydın Üniversitesi, Sosyal Bilimler Enstitüsü, İngiliz Dili ve Edebiyat1 Doktora Öğrencisi, aysegulelci@stu.aydin.edu.tr, ORCID: https://orcid.org/00000002-5179-5507.
} 
siyahîlerin kültürel kimliğini şekillendiren faktörler ve Amerikalı siyahîlerin kültürel kimliğini inşa etme süreçleri, dönemin gelişen olayları ışığında ele alınmaktadır.

Anahtar Kelimeler: Sevilen, Kölelik, Afrika Kökenli Amerikalılar, Siyahîler, Kültürel Kimlik ve Melezlik.

\section{Introduction}

Published by Toni Morrison in 1987, Beloved deals with the slavery life of 'dislocated' and 'displaced' Kentucky people in America in nineteenth century. As a result of the dislocation and displacement, the Kentucky people's life turned out to be more complicated and aggrieved. Dislocation is described as transportation from a well-known place to an unknown place; from one country to another (Ashcroft et al., 2007). According to Heidegger, dislocation leads to "not-at-home-ness" and "unhousedness" (Ashcroft et al., 2007, p. 65). Africans are estranged from their families, ethnicities, nations, lands, and cultures. They are reconstructed by their white landowners in America with undeniable African customs and passions to expose different experiences, customs, and cultures. The African American people recreate a 'hybrid' identity which is different from both Native African and Native American. The novel includes a perspective regarding cultural hybridity which is justified by the view that Africans should stick to their own culture, acquaint themselves with other cultures, but also remember that they should not attach to the other cultures blindly. Morrison recognizes the Africans need for interaction with other cultures on the condition that they should not forget their ethnicity, language, custom, and language or not be assimilated, in short.

Black Africans search for a new identity through their experiences in the shadow of trauma. Their traumatized past recreates, reasserts new identities. The repressed memories expose the individuals to the process of constructing selfidentity. They attempt to reconnect with their 'ancestral past', their living or dead relatives.

'European American', 'capitalist patriarchy' and 'white-supremacist' (Keizer, 1999, p. 105) started the process of slavery. In the beginning, the Africans worked as indentured laborers then the colonizers prepared some laws to prevent them from running away to their lands for the blacks; the term 'Negroes' was used for the first time in 1661, and some rules related to the babies of the slaves were enacted (Stetson, 1982). The government of Virginia prepared nine laws, which related to the infants of the slaves; the new-born child 
had the same status as its mother in 1662. A big change could be seen sharply in English Common Law at that time; "A child's status is determined by the father's condition" was changed to "a child's status is determined by mother's condition." (Stetson, 1982, p. 72). Thus, the white man who had sexual freedom legally was not responsible for the babies of the black women. An enacted law stated that; "All Negro, mulatto and Indian slaves shall be held, taken and adjusted to real estate in the same category as livestock and household furniture wagons and goods" in 1705 (Stetson, 1982, p.73). New laws in other areas such as education, religion, marriage were passed for slaves and the Whites dehumanized the Blacks (Stetson 1982). The slave trade ended legally in 1865 and African Americans emerged as a new race to construct a new identity.

\section{Discussion}

America is a multicultural nation with different cultures; one of the most important cultures with negative experiences is the African American culture. The factors affecting African American identity are diversified. The White Hegemony oppresses Black's life, community, and heritage through oppression. The Blacks must develop an identity under the shadow of racism. Some factors are affecting African American's identity. The black color is a major factor in constructing an identity, which implies the way of identifying one; how the blacks define themselves and how the others view the blacks. This means being categorized into a social category and having different social characteristics (Fearon, 1999).

Identity is described as the characteristics, beliefs, feelings which make people different from other people. Identity is a 'transcending discourse' in history and place; it is 'not something that already exists' (Hall, 1990, p.225). Identity is a process of 'production' that is never complete (Hall, 1990, p.). It can be handled with the Diasporas of West post-colonial subject in terms of representation of the Afro- American Blacks. The blacks are at the center of the discourse of cultural practices and norms which questions cultural identity. Culture and history can change the cultural identity constructed through myth, narrative, fantasy, and memory. Cultural identity is the indication within the discourse of culture and history (Hall, 2003).

Culture is a term that is defined as a pattern of the same group of Black and White communities. African American culture is formed by African American who is one of the races of different nationalities living together in America since the 1800s. This is the emergence of a new culture that is distinct from the Americans and Africans. African American culture is a subculture of 
American culture and it is at the same time a part of American culture, distinct from the dominant culture. This culture means a connection of different parts including traditions, customs, discourses, and technologies.

Jackson Ronald (1999) defines cultural identity as the feeling of belonging to a society, which reconfirms self-identity. It is the relationship between human beings, cultures, and interplays. He states that cultural identity is comprised of values, mores, meanings, customs, and beliefs used to relate to the world. Lifestyle; dressing style; belief system; rituals; race, and skin color describe a society that helps to identify people with others in the view of the same cultural heritage.

Homi Bhabha points out that cultural differences in a homogenous society should not be viewed as the free play of contrast and numerousness. With the cultural difference that contributes to the social paradox, new knowledge and methods should be open to debate (1994). The slaves question their race whether they are African or American. They are squeezed between two cultures because they have bi-cultural experience and are unable to identify themselves as American or African. They have no sense of a complete connection to American culture or African culture to abandon their own culture to live in America. As different cultures (African culture and American culture) come together, cultural hybridity occurs; foreign people are disconnected from their own origin and ethnic heritage. Bhabha states that foreign culture is based on the inter-cultural or inter-cultural hybridity of culture (1994). Cultural identity stands for hybrid, resulting in the experience of new cultures while simultaneously missing something from one's own culture (Bhabha, 1994).

The relationship between Black African and White American cultures is called 'hybridity' that is described as a mixture of linguistic, discourse, and culture. Cultural hybridity, a fusion of language, discourse, and culture should not be seen as homogenizing the various parts, but rather as combining many parts (Zapf, 1999). The most significant observation in Beloved for cultural hybridity is that they lose their mother tongue. In his childhood, a slave is being sold and taken to another country. The childhood, the member of the family, and the mother tongue are, therefore, completely forgotten. Sethe forgets her mother tongue after learning a new language through slavery in America. She cannot remember what she told her mother, Nun (Morrison, 1987). Forgetting their mother tongue and being renamed are the most significant samples in the novel.

The names are inseparable parts of a culture, a significant part of identity, and a heritage. Genevieve Fabre stresses that names are a remarkable message 
for the legacy (1986). The whites evaluate all the blacks in the same category. The names of the slaves are changed when they are sold. The first example related to names in the novel is that three slaves have the same name; there is only one special letter differentiate them; Paul A Garner, Paul D Garner, Paul F Garner (Morrison, 1987). When they are bought by Garner, the slave owner, he has the right to give his slaves a name. The second example from Beloved is that the names have a senseless meaning. Sixo is a slave's name refers to the number of 'six' and on the way to run away from slavery, he calls his mother ' Seven-o' (Morrison 1987). The Blacks are materialized by numbers calling, and these meaningless names indicate that the Whites do not love and appreciate Black slaves. The third example associate with the name is Stamp Paid that Joshua renames himself. Joshua is a slave who is obliged to give his wife to his slave owner's son in return for his debts (Morrison, 1987). Another example from the book is that Baby Suggs refuses to use the name, Jenny Whitlow, given by her owner, Mr Garner, who insists that Baby Suggs is not an appropriate name for a liberated Black (1987). She does not accept her new name so she presents herself as Baby Suggs because she avoids loosing her identity. She feels if her husband looks for her one day, he will easily find her (1987). In an interview, Morrison describes this condition as Africans not only lost their identities but also lost their families and tribes. Therefore, she remarks that after death they can't connect with their ancestors, which causes a big psychological problem (Le Clair, 1983).

"Hybrid," with traces of ancient and modern civilizations, includes a cogent display. Cultural hybridity is an articulation of culture, as Bhabha describes, that the theoretical definition of cultural hybridity is not based on multiculturalism or the diversity of cultures, but rather on cultural articulation. Examples of Beloved's cultural hybridity are another language and a modern style of music. A modern genre of music, which is different from original African and American music, played in Cincinnati, where after slavery the slaves are settled. Morrison states that "Just outside music it lay with a cadence not like theirs" (1987, p.68). The miscegenation is rising biologically - a hybrid teacher in Cincinnati's in Beloved- and culturally. On one side, the slave's mother tongue, African music, food; on the other side the language of English, American music and food. The result is a mixing race, language and culture.

Edward Said remarks that cultural and aesthetic areas should be connected simultaneously and he is aware that this synchronization is very difficult because of isolation (1993). In order to become truth, one culture should not be inferior to the other. Within American society, American culture 
and African culture should be comparable, which means that Africans should be influenced by American culture and African culture should influence Americans. Unfortunately, it is hampered by racism. Afro-American culture is made up of Black Africans' heritage and White Americans' culture. Afro Americans have a dilemma about how to maintain the cultural roots of Africa and how to keep up with American culture.

One dilemma of African Americans is related to 'inner freedom' when the slaves discover themselves as human beings after liberation, also the outside world imposes freedom on them. While Rodrigues asserts that the slaves achieve "inner freedom" after emancipation (1991), the culture, the outsiders disturb it. In Beloved, the first factor to achieve inner independence is that Sethe feels herself free independently, and the second factor is that society asserts ownership of that free person. Being self-confident and individually declaring independence cannot be true at the same time (Morrison, 1987).

Purity is another major cultural hybridity problem. Both cultures lack purity but contain hybridity because transculturation implies mutual loans between cultures (Rosaldo, 1995). He points out that on the land of intertwining, hybridity and purity cannot be isolated from each other. In a multicultural nation, strictly original construction of identity is unlikely, so the combination of indigenous and colonial culture forms a third space between the Whites and the Blacks (Fludernik, 1998). The third space relates to the deeper parts between interacting cultures, a liminal space that gives rise to something special, something fresh and unrecognizable, a new area of meaning and identity negotiation. In this "intermediate" space, new cultural identities are created, transformed, and continuously in a state of becoming. In Beloved, the culture of Cincinnati is a combination of American and African cultures where Black people have a common destiny, history, custom, tradition, language, discourse, and identity. Sethe is such an outcast, a lonely woman in Beloved that no one wants to meet her and, no kids want to play with her child, Denver. No one meets and embraces them because they are the other, and this othering forms a new identity in this city. In Beloved, Halle and Sethe's marriage is related to $\mathrm{Mr}$ Garner's and Mrs Garner's marriage. The bad mate attempts to knit old wedding clothes and prepare some corn as a wedding meal (Morrison, 1987). They are influenced by the marriage style of the White, and this Blacks marriage transition is an example of cultural hybridity. The cultural differences reforms a new culture in the terms of hybridity, national, cultural, ethnic, and individual identities are constructed in the discourse of identity. Ethnicity, race, social class, social status, sexuality, and language are the determiners of cultural 
identity. The Blacks live in America to build a new life that is different from the lives of the Black and the White.

Dehumanization is a way of humiliation in which the blacks are treated as not fully human. The Whites are scorning, insulting, and humiliating the blacks who feel less than they do. The use of terms such as ' slaves ', ' niggers ', ' beast ', and ' animals ' insulted the slaves and compared them to animals. The schoolteacher, the master who comes to organize the farm after the death of the slave owner, Mr Garner, states that "[A] slave looks like a horse" (Morrison, 1987, p.86). If you beat a horse so much, you're going to lose it. Sethe is whipped so much that she has a hysteria attack that leads to infanticide (Morrison, 1987). Another example from Beloved is that Sixo is a slave who steals a shoat and eats it and eventually is punished by a schoolteacher who ties him to a rope like an animal, sleeping among the sheep and the cows in a barn during the night (Morrison, 1987). The school teacher also teaches two slave boys how to read and write in Beloved; one of the boys would like to mention the features of Sethe. The schoolteacher wants him to split the paper into two columns; one column is for human characteristics, the other column is for animal characteristics. When the boy writes Sethe's characteristics on the human side, the teacher warns him, "No, no ... Put her human characteristics on the left (side): her animals on the right (side)" (Morrison, 1987, p.109). Hearing that Sethe feels sad and humiliated. The Black men are not recognized as men, $\mathrm{Mr}$ Garner is praised for recognizing the Blacks as men. He states that "my niggers are men of all kinds ... men of all kinds." (Morrison, 1987, p.10-11). He believes he buys them as men and raises them as men, human beings. The schoolteacher, however, objects to the Mr Garner's idea and argues that the Blacks are not men, so he suggests that Mr Garner should change his belief; "Beg to differ Garner. Ain't no nigger men" (Morrison, 1987, p.18). The schoolteacher claims that Garner will continue to differ (Morrison, 1987). But with these words, $\mathrm{Mr}$ Garner defends his idea: "If you are a man yourself, you want your niggers to be people too" (Morrison, 1987, p.10-11). Although Mr Garner is a White Slaveowner, he respects the Blacks and does not discriminate against them.

In Beloved, Mr Garner views the black slaves as human beings. When he guides the slaves on the farm, he encourages his slaves, Sethe and Halle to marry. Not only does he encourage them to be capsulated, but he also encourages them to marry. Mr Garner supports them to set up an illegal family that leads to a dysfunctional family which ended with destruction. In Beloved, Sethe loses her children one by one and the baby's life, ended in Sethe's hands. The other thirteen-year-old sons, Howard and Burglar, run away with the war 
excuse. Like Sethe's family, Baby Shugg's family also is destructed. Baby Shugg has eight kids, but she has forgotten all her kids, and she believes that her four kids will be taken as slaves and the other four will run away. She admits as a mother that she forgets all her kids. She remembers that "My firstborn. All I can remember of her is how she loved the burned bottom bread... eight children and that's all I remember" (Morrison, 1987, p.5).

According to American laws, the slaves have no right to get married, establish a family, and mating. This practice is against the law so it is wrong. The schoolteacher comes to the Sweet Home for changing the wrong practices of Mr Garner whose wrong practice objects to the law that is letting the slaves buy themselves. In Beloved, Halle works even on Sundays in order to save money to gain her mother's -Baby Shugs- freedom (Morrison 1987). Mr. Garner allows slaves to have guns. The schoolteacher seizes the slaves' guns so they are lack of the capability to hunt and eat. The schoolteacher symbolizes the cruel White Mem who enforces the laws in the Sweet Home. All of these practices are against law and lead to loss of the two niggers (Morrison 1987).

The Blacks can experience anxious feelings in response to dehumanization, exploitation. The reasons behind the feeling of anxiety, as Franz Fanon puts them, are scorning, insulting, humiliating, namely the sense of inferiority that leads to apprehension in Black Skins White Masks. He points out that "[T]he Negro having been made inferior, proceeds from humiliating insecurity through strongly voiced self-accusation to despair" (Fanon, 1967, p. 60). In Beloved, for example, Sethe's feeling that she has no hope, namely that the thought of desperation causes murder. She wants to kill her children to save them from the miserable life because rape, whipping, and hunger lead to crime. Sethe has a scar that is like a chokecherry tree on her back. She is frightened on her back and is whipped like an animal by the slave owner's nephew. As if she could not raise her voice to her owner, she kills her own baby. She cannot attempt to attack her owner while being whipped.

One reason to accept their fate is that the slaves are convinced that the violent techniques are useless for the slaves. (Fanon, 1967). The Black Slave revolt is severely oppressed by violence. The tanks, the fighter plane, guns, and bombs represent the power of the Whites. When the Blacks recognize that they have to act, they are frightened by bombs, guns, jails, and police. The Blacks break themselves from attacking, so Fanon explains them as "[T]hey're losers from the start" (Fanon, 1967, p.25). Sethe feels her strength is not enough to struggle with the White owners, so she struggles with herself. That is why she 
attempts to kill her own defenseless kids. The other reason to accept their fate is that they do not want to be beaten in front of their kids. Baby Shuggs says that she is always afraid of a Whiteman knocking her down before her kids. She does everything properly because she does not want her children to see her being knocked down (Morrison, 1987). Baby Shugss instructs her daughter-in-law to follow Whites' laws by saying, "To lay it down, sword and shield" (Morrison, 1987, p.118). Toni Morrison wants to give a message to her readers by black characters who revolt for seeking their rights. She uses the prototype of Alfred Georgia who kills his slave owner in Beloved (Morrison, 1987).

The abrogation of slavery leads Black Diaspora, as Patton claims that it refers to multinationality, relocation, and the struggle of ingenious people in America. He points out that the black diaspora between Africa and America is complicated and both nations have a shared history of slavery, hybridization, colonialism, revolt, and rebellion (Patton, 2006). Black Diaspora highlights the common experiences of the new world's oppressed Black communities. Old culture dispersal leads to new diasporic identities. The Black consciousness is shaped by the desire to return to the motherlands, to the interdependence of the Blacks and to marginalize the new residence (Safran, 1991). The Blacks are fighting for freedom, equality and fairness, and this struggle ultimately affects the awareness of Black Diaspora (Patton, 2006). Although the identity is unsteady, it is surrounded by hope, equivalence, and circumscription (Castronovo, 2002). In Beloved, freedom is such a great desire that it is unavoidable for all ages, including Sethe, Paul D, Halle, and Sixo who run away from Sweet Home with great expectations of forming a new life and identity. While Baby Shuggs is very old -sixty years of age-, she does not reject her son's offer. He is such a self-sacrificing person who sacrifices his freedom for the freedom of his mother. Halle tries to save money even on Sundays to achieve the freedom of her mother. Baby Shuggs behavior shows how important freedom is for a slave, after just five years of living as a free person. This selfdevotion is endorsed by Morrison..."... after five years of freedom given to her by her last child, who bought her future with, exchanged it..."( Morrison, 1987, p. 209). The oppressed exploited people have a power of solidarity even though Baby Shuggs gets freedom that has no sense in her last days, which is a hard offer to reject.

After being rescued from slavery, society turns into uneasy and comfortless exercise of survival between past and present (Bhabha, 1994). After freedom, the days of slavery are not forgotten, in Beloved, there are numerous flashbacks in which Sethe is unable to save herself from her past. She purposely 
recalls the past and builds memory and frequently uses words of 'disremember' and 'remember' for whipping, stealing her milk and killing her baby (Morrison, 1987). As Jackson points out, cultural identity describes the events in the past, present, and future (1999). In Beloved, after years, Sethe and Paul meet and recall the terrible days. Sethe thinks the Whites dirty her and do not allow her to value herself, and she can no longer remember her identity. The White supremacy could also pollute her children so that she needs to control them by committing infanticide, thereby achieving her goal by removing her children from the dirt (Morrison, 1987). The sense of release from dirtiness, captivity cannot be forgotten under any circumstances. The past still exists in the memory even after emancipation.

Religion is a significant element of identity shaping as well as gender, sexism, ethnicity, and nation. A non-Christian African could not travel to Virginia in 1670, it was legally banned (Guy-Sheftall, 1982). Being a Christian is an African slave's positive discrimination. It is a way of spreading Christianity to have the right to arrest a non-Christian slave. The Christian Americans argue that the dark areas are illumined by Christianity. Sugirtharajah makes it clear that the old empire is using the excuse of ignorance The Protestant White man claims that the aboriginals are ignorant and the Bible enlightens them which is a "light to dark places" (2005, p.222). In the life of converted people, a reconstruction of ethnicity and religion can be seen deliberately that Sugirtharajah defines this process as "they themselves were shaped and moulded their identity redefined" $(2005, \mathrm{p} .2)$. A hybrid teacher in Beloved teaches how to read and write to Denver. If she needs the teacher's help, the teacher helps her and gives her a Bible as a gift (Morrison, 1987). The Bible which Denver reads everyday is an exchange for the help. The explanation of this understanding the bible, one obeys rules. The Bible influences financial, economic, and political aspects (Sugirtharajah, 2005) and also cultural spheres.

America has been superior to other countries economically, socially, philosophically, and militarily since its establishment. This dominance is based on the belief in "Promised Land" and "City on a Mountain." While being very old, these concepts also influence American citizens. America's first settlers thought that God gave this land, so it is called "Promised Land." America has rich materials, a favorable climate, and a good geographical position. The indigenous people and the Red Indians were expelled from their land. The colonists inhabited this land and believed that this land was a gift from God to them, ' Promised Land.' They ignored Native Americans' rights, and use everything to their advantage. Puritan John Winthrop also claims that America 
should be an outstanding country and said, "[W]e are going to be like a city on a hill, the eyes of all nations are on us." (Kennedy, 1961). America's 35th president, John Kennedy, supports the idea of City on a Hill' that everybody watches them so that their government should be' A City on a Hill' both nationally and locally. White men should, therefore, understand their immense obligations and responsibilities.

\section{Conclusion}

In conclusion, the novel by Morrison also illustrates us how white supremacy has been exploiting the Blacks for years and how racism, sexism, patriarchy, and religion are the raw materials of cultural identity. Although all Africans may come from different backgrounds, the obvious thing is that they are not disconnected from their own culture or adapted to the new culture. Therefore, African Americans are not embraced or reflected in the mainstream American culture, they have difficulty in constructing a strong identity. They attempt to construct a new cultural identity that is different from their ancestors' culture and white's culture. The Blacks are affected by the behavior of Whites. The behavior of Whites has an impact on Blacks. Sethe and Beloved learn how to have a sense of belonging and how to behave like a master from their white masters. Sethe has committed infanticide because she believes that Beloved, her daughter, is hers and that she has the right to end her life. Like Sethe, Beloved behaves as the master of her mother. She makes her mother do anything that she wants. African American identities are constructed through the experience of slavery, oppression, and racism.

\section{REFERENCES}

ASHCROFT, B., GRIFFITHS, G., \& TIFFIN, H. (2007), Post-Colonial Studies: The Key Concepts, 2nd Edition, London: Routledge.

BHABHA, H. K. (1994), The location of culture. London: Routledge.

CASTRONOVO, R. (2002). "Race and other clichés", American Literary History, 14(3), 551-565.

FABRE, G. (1986), "Genealogical archeology: Black women writers in the 1980's and the search for legacy", Revue française d'études américaines, 461-467.

FANON, F. (1967), Black skin white masks, New York: Grove P.

FANON, F. (1963), The wretched of the earth, New York: Grove P. 
FEARON, J. D. (1999), What is identity (as we now use the word). Unpublished manuscript, Stanford University, Stanford, Calif.

ROSALDO, R. (1995), Forward: Hybrid Cultures: Strategies for Entering and Leaving Modernity. London: University of Minnesota Press. Retrieved from http://blogs.ubc.ca/last201spring2017/files/2017/01/garciacanclini_hybrid-cultures2.pdf

GUY-SHEFTALL, B. (1982), "Gloria T. Hull, Patricia Bell Scott, and Barbara Smith, eds., All the Women Are White, All the Blacks Are Men, but Some of Us Are Brave, Black Womens Studies", The Journal of Negro History, 67(3), 271-272. doi: 10.2307/2717398

HALL, S. (1990), Cultural identity and diaspora. (2003), Da diáspora, Belo horizonte: UFMG, 36.

HISTORIC SPEECHES - John F. Kennedy Presidential Library \& Museum, Retrieved from https://www.jfklibrary.org/JFK/Historic-Speeches.aspx.

JACKSON, R. L. (1999), Negotiation of Cultural Identity: Perceptions of European Americans and African Americans, Westport Connecticut: Praeger Publishers.

KENNEDY, R. (2017), Building a City on a Hill. Political Science Building a City on a Hill.pdf

KEIZER, A. R. (1999), "Beloved: ideologies in conflict, improvised subjects", African American Review, 33(1), 105-119.

LE CLAIR, T. (1983), An interview with Toni Morrison, anything can happen: interviews with contemporary American novelists, In $\quad L$. MacCaffery (Ed.) Urbana, IL: University of Illinois Press, (pp. 252261).

MORRISON, T. (1987), Beloved: a novel, New York: Penguin.

PATTON, T. O. (2006), "Hey Girl, Am I More than My Hair?: African American Women and Their Struggles with Beauty, Body Image, and Hair”, NWSA Journal, 18(2), 24-51. doi: 10.2979/nws.2006.18.2.24

RODRIGUES, E. L. (1991), "Telling of Beloved", Understanding Toni Morrison's Beloved and Sula, 2 (2) Spring, 61- 82.

SAID, E. (1993), Culture and imperialism, London: Vintage Books. Pdf. 
SAFRAN, W. (1991), "Diasporas in Modern Societies: Myths of Homeland and Return", Diaspora: A Journal of Transnational Studies, 1(1), 83-84. doi: $10.1353 / \mathrm{dsp} .1991 .0004$.

SALEEM, T. F. (2010). The village mother in selected works of Toni Morrison (Electronic Theses \& Dissertations) Jack N. Averitt College of Graduate Studies (COGS) : Georgia Southern University, Retrived from https://digitalcommons.georgiasouthern.edu/cgi/viewcontent.cgi?article $=1180 \&$ context $=$ etd

SUGIRTHARAJAH, S. R. (2005), The bible and empire postcolonial explorations, New York: Cambridge University Press.

STETSON, Erlene, (1982). African Diaspora, Ph.D. "All the Women Are White, All the Blacks Are But Some of Us Are Brave", Black Women's Studies. New York: Feminist Press.

ZAPF, H. (1999). "The theoretical discourse of hybridity and the post-colonial time-space of the Americas", ZEITSCHRIFT FUR ANGLISTIK UND AMERIKANISTIK, 47(4), 302-310. 
